\title{
Des «Public-Relations» aux Relations Publiques - La doctrine européenne de Lucien Matrat
}

Philippe A. BOIRY

\section{DES « PUBLIC-RELATIONS * AUX RELATIONS PUBLIQUES}

La doctrine européenne de Lucien Matrat

Questions contemporaines

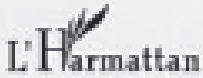

BOIRY, Philippe.

“Des «Public-Relations» aux Relations Publiques - La doctrine européenne de Lucien Matrat".

Paris: L’Harmattan, 2004. 387 p.

\section{Ana Maria Walker Roig Steffen FAMECOS/PUCRS}

- m seu livro "Des 'Public-Relations' aux Relations Publiques - La doctrine européenne de Lucien Matrat", Philippe Boiry explora os fundamentos sociopolíticos das relações públicas, segundo a percepção de Lucien Matrat. Na primeira parte da obra, o autor discorre sobre a sugestão do título bilíngüe, estabelecendo o que se pode chamar de uma migração de significados desde o nascimento das relações públicas nos Estados Unidos, no início do século $X X$, até sua absorção pela França, por volta da década de 50, provocada pela retomada da produção industrial no período pós-segunda guerra mundial. Para Matrat, as relações públicas consolidam-se, essencialmente, no sentido da expressão "l`estratégie de la confiance", associando a díade fatos econômicos e realidades sociais para conquistar a confiança da sociedade junto às organizações.

$\mathrm{Na}$ sociedade norte-americana, a identificação desta atividade foi motivada pela necessidade das organizações de adequarem-se a uma nova realidade que lá se implantara no final do século XIX. Nesse período, a opinião pública começa a rebelarse contra o mito americano da "idade de ouro", que enriquecia o empresariado às custas do empobrecimento da sociedade. Instalou-se a era da prestação de contas das organizações lucrativas junto à opinião pública, por meio da imprensa. Seguindo um modelo de estratégia defensiva e apesar de ainda não ser a atividade reconhecida nominalmente como public relations, inauguram-se as suas premissas.

Foi Ivy Lee, o jornalista e assessor de imprensa, encarregado de gerenciar uma greve de operários de uma mina de carvão, quem desvelou o óbvio: a necessidade de fornecer informações autênticas, levando em conta o interesse dos públicos. A consideração do interesse público, por mais evidente que possa parecer atualmente, implica uma verdadeira revolução no comportamento das empresas norteamericanas, criando uma base essencial para o surgimento das relações públicas: a criação de um capital de confiança para conquistar a adesão do público. A evolução deste pensamento leva os administradores americanos a associar a atividade ao que denominaram função de gestão das empresas, no mesmo nível em que se colocavam as funções diretivas, financeiras ou comerciais. Simultaneamente, surgem as primeiras publicações de obras enfocando as relações públicas. Inicia-se, assim, a construção de um corpo teórico que culmina na implantação da disciplina de relações públicas, na Universidade de Nova Iorque, em 1913.

Matrat identifica o período da migração da atividade dos Estados Unidos para a França: quando o Pla- 
no Marshall, com aporte financeiro, impulsionou as organizações às missões de aumento da produtividade. A associação deste objetivo à atividade de relações públicas levou a direção do Centre d'Études pour l'Accroissement de la Productivité a organizar uma viagem de estudos aos Estados Unidos com o intuito de descobrir as public relations. O exercício da atividade iniciou-se na sociedade francesa inserido nas multinacionais norte-americanas que lá se instalaram.

A associação da nova atividade à propaganda comercial, fundamentada no princípio de conduzir o comportamento humano a favor de um objetivo organizacional, ao adaptar o indivíduo a uma sociedade ou levando-o ao ato de consumo, estabelece uma confusão epistemológica entre as duas atividades. Lucien Matrat eleva-se contra esta percepção, a qual considera equivocada, e insiste no fato de que relações públicas e propaganda são atividades opostas. Buscando embasamento no objetivo de cada uma, o estudioso cria uma espécie de ontologia, denominada Manifesto de Relações Públicas e publicada no capítulo francês da IPRA (International Public Relations Association-01/68). Dirigindo-se aos publicitários, Matrat estabelece um parâmetro para que cada atividade identifique seus objetivos e domínios específicos:

à publicidade, cabe o objetivo de criar o desejo; às relações públicas, o de merecer a confiança... são duas coisas diferentes, mas uma e outra, necessárias ao sucesso da empresa. Nada nos opõe. Tudo nos distingue. Nós não somos vós. Vós não sois nós, mas nós e vós, por caminhos diferentes, que não podemos confundir, contribuímos para o sucesso da empresa.

O pensador enfatiza, ainda, o código profissional das relações públicas, aprovado em 1954 pela Federação Francesa de Publicidade: “As informações de relações públicas devem limitar-se à exposição dos fatos e isentar-se de todos os argumentos da publicidade comercial e da propaganda" (p. 45).

Na segunda parte, a obra apresenta os fundamentos da doutrina de Matrat para a nova atividade baseados em uma lógica de associação entre fatos econômicos e realidades sociais, já expressa por Ivy Lee, para quem o trabalho de relações públicas consistia em "traduzir as palavras dólares e centavos em termos humanos (p. 112)." Incluindo a atividade no ramo das disciplinas sociais e caracterizando-a pela tríade ética, ciências humanas e comunicação, Matrat posiciona as relações públicas como uma área funcional nas organizações. O profissional intervém largamente no estilo da direção, ao modo da direction à la française: a busca constante da decisão que leva em conta todos os elementos que contribuem para o resultado comum, com ênfase no fator humano. A inserção da comunicação no processo de relações públicas justifica-se pelo fato de que a ativi- dade desenvolve-se em um sistema social. A comunicação é ferramenta indispensável na implantação do sistema de informações gerenciais, garantindo o sucesso de uma ação de relações públicas, a qual repousa no axioma: escutar, muito e atentamente, antes de falar. Boiry dedica um espaço na obra para explanar uma metodologia de comunicação a ser aplicada em relações públicas e define, ainda, alguns princípios de relações com a imprensa, posicionando-a, em razão da sua audiência, como um importante meio a ser considerado. Para se fazer entender melhor, utiliza a analogia das relações públicas como uma orquestra sinfônica, posicionando a imprensa como o primeiro violino.

A terceira parte da obra dedica-se à aplicação e utilidade das relações públicas no mercado de trabalho e sua inserção na esfera social e governamental francesa, com a criação de decretos de regulamentação e legalização do seu exercício profissional pelas entidades de classe, como a Confederação Européia de Relações Públicas e a Associação Francesa de Relações Públicas. Matrat cria o Código de Atenas, apresentado em maio de 1965 e reconhecido pela Associação Internacional de Relações Públicas (IPRA) como o código internacional de ética da profissão. Boiry reúne uma série de argumentos que posicionam as relações públicas como uma profissão específica, com finalidades e objetivos próprios, às voltas com problemas de natureza sociológica e situações de crise, contrapondo-a à publicidade e propaganda. Esta, segundo a crítica de Matrat, limita-se a explicar situações geralmente complexas em slogans simplistas, veiculados em espaços comprados na imprensa. Disserta, ainda, sobre o exercício das relações públicas no mercado de trabalho. No final da obra, apresenta três exemplos de aplicação prática da atividade.

Boiry encerra o livro com uma pérola verbal expressa por Lucien Matrat: "Se um dia alguém fizer um estudo sobre a nossa doutrina, poderá nele incluir: Muitas vezes estamos errados em ter razão cedo demais, mas estamos sempre errados em ter razão tarde demais". Por fim, coloca a questão: "Será que ele era profeta até esse ponto?" (p. 270). mfamecos 